\title{
Ichnology of the Palaeogene Richmond Formation of eastern Jamaica - the final chapter?
}

\author{
Ron K. Pickerill \\ Department of Geology, University of New Brunswick, Fredericton, New Brunswick E3B 5A3, Canada \\ and \\ Stephen K. Donovan, Eamon N. Doyle and Harold L. Dixon \\ Department of Geology, University of the West Indies, Mona, Kingston 7, Jamaica
}

\author{
Date Received November 1, 1992 \\ Date Accepted January 12, 1993
}

\begin{abstract}
Previously unrecorded ichnotaxa from the Palaeogene Richmond Formation of eastern Jamaica, namely Cosmorhaphe cf. gracilis, Helminthoida crassa, Paleodictyon? isp. and Taenidium cameronensis, are described. The ichnotaxa are assigned to a previously defined deep-water Scolicia ichnocoenosis characteristic of turbiditic strata. The general exclusion of graphoglyptids in these strata is believed to reflect a combination of the relatively shallowwater depths in which the turbiditic strata accumulated, the abundant organic matter available for biological consumption, and the existence of fluctuating dysaerobic/anoxic and oxygenated conditions at, or immediately below, the sediment-water interface.
\end{abstract}

Les ichnofossiles auparavant non enregistrés provenant de la Formation paleogène de Richmond de l'est de la Jamaïque, soit Cosmorhaphe cf. gracilis, Helminthoida crassa, Paleodictyon? isp. et Taenidium cameronensis, sont décrits. Ces ichnofossiles sont assignés à l'assemblage d'eau profonde Scolicia antérieurement défini, caractéristique des strates de turbidites. L'absence générale de graphoglyptides dans ces couches est considérée comme reflétant une combinaison de la faible profondeur relative à laquelle les strates de turbidites se sont accumulées, l'abondance de matière organique disponible pour la consommation biologique et l'existence de conditions anoxiques et oxygénées fluctuantes à l'interface eau-sédiment ou immédiatement en-dessous.

[Traduit par la rédaction]

\section{INTRODUCTION}

The Richmond Formation of Jamaica underlies and is exposed over a considerable area of the eastern part of the island (Fig. 1), and comprises approximately $1200 \mathrm{~m}$ (Green, 1977; Mann and Burke, 1990) of intensely folded and faulted, essentially siliciclastic strata with locally developed nodular limestones, and calcalkalic and dacitic volcanic rocks. The sequence, essentially Eocene to possibly Paleocene (Palaeogene) in age (Jiang and Robinson, 1987; Scott, 1987; Mann and Burke, 1990), accumulated in an intra-arc rift in a large fan delta-submarine fan system (Wescott and Ethridge, 1983; Ethridge and Westcott, 1984) in which marginal-, shallow- and relatively deep-marine environments can be recognized. Characteristic lithofacies associated with these environments have been outlined by the latter authors and Pickerill and Donovan (1991).

Pickerill and Donovan (1991) and Pickerill et al. (1992) provided information on the ichnology of the marginal-, shallow- and deep-marine lithofacies associated with the fan delta-submarine fan system, and recognized two environmentally-restricted, mutually-exclusive ichnocoenoses, namely, a marginal- to shallow-marine Thalassinoides ichnocoenosis and a relatively deep-marine $S$ colicia ichnocoenosis (see below). As noted by Pickerill and Donovan (1991), somewhat surprisingly the Scolicia ichnocoenosis apparently did not contain any graphoglyptid (sensu Fuchs, 1895;

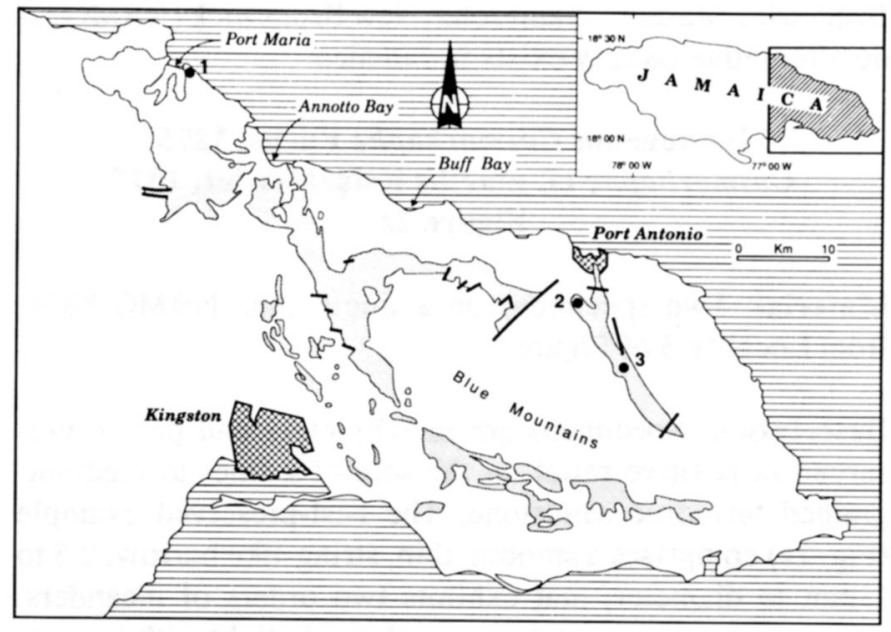

Fig. 1. Geographic distribution of the Richmond Formation (stippled) of eastern Jamaica. Numbers 1 to 3 refer to localities from which trace fossils described in the main text were collected. 1 - coastal outcrop immediately to the east of the small headland on the eastern side of the bay of Port Maria; there, strata of the Roadside Member of the Richmond Formation (early Eocene - see Mann and Burke, 1990) are exposed; approximate grid reference 593534. 2 - cliff outcrop in undivided Richmond Formation strata on the northeast bank of the Rio Grande river, west-southwest of Fellowship; approximate grid reference 737449. 3 - cliff outcrop in undivided Richmond Formation strata on the east bank of the Rio Grande river, south of Comfort Castle; approximate grid reference 756417 . 
Seilacher, 1977) burrows. Such burrows, representing relatively permanent and complex systematically-patterned feeding or farming systems (agrichnia) or, alternatively, highly specialized behavioural activity, are elsewhere particularly prevalent in Mesozoic and younger deep-sea flysch sequences (Miller, 1991). However, subsequent examination of three well-exposed and generally continuous sections within the formation (Fig. 1) has revealed the presence, albeit uncommonly, of two (Cosmorhaphe cf. gracilis, Paleodictyon? isp.), possibly three (Helminthoida crassa), graphoglyptid ichnotaxa. Additionally, a relatively abundant but previously unrecorded ichnotaxon (Taenidium cameronensis) that is, elsewhere, an uncommonly reported form (see D' Alessandro and Bromley, 1987), also occurs at one of these sections.

The purpose of this short contribution is, therefore, to document and briefly describe these unreported ichnotaxa, to provide a brief discussion on their palaeoenvironmental distribution with respect to the previously defined Thalassinoides and Scolicia ichnocoenoses, and to provide a possible explanation of the general exclusion of graphoglyptids within the relatively deep-water lithofacies of the Richmond Formation.

\section{SySTEMATIC ICHNOLOGY}

Specimens are described alphabetically. Because of sampling difficulties only two specimens were collected; these are deposited in the Division of Natural Sciences, New Brunswick Museum, Saint John, New Brunswick (NBMG) as no alternative facility exists in Jamaica.

Ichnogenus Cosmorhaphe Fuchs, 1895 Cosmorhaphe cf. gracilis Książkiewicz, 1977 Figure 2a

Material: Two specimens on a single slab, NBMG 8844, from Locality 3 of Figure 1.

Description: Specimens are incompletely and poorly preserved in positive relief on the sole of a fine- to mediumgrained turbiditic sandstone. The best-preserved example (Fig. 2a) comprises a smooth, thin, string-like burrow, 0.8 to $1 \mathrm{~mm}$ in diameter, that exhibits two orders of meanders. Larger first-order meanders are relatively tight with a wavelength of ca. $30 \mathrm{~mm}$ and amplitude 15 to $21 \mathrm{~mm}$; second-order meanders, somewhat loop-like, are higher $(5-12 \mathrm{~mm})$ than wide (3-6 mm). The second example exhibits similar characteristics, but is extremely narrow, with a diameter of $0.5 \mathrm{~mm}$, and slightly more irregular in overall appearance.

Remarks: Cosmorhaphe is a graphoglyptid trace fossil that occurs typically, though not exclusively, in deep-water flysch successions of Cambrian to Holocene age. To our knowledge, Cambrian recordings of the ichnogenus (for example, Narbonne et al., 1987) are from relatively shallow-water neritic settings; post-Cambrian occurrences are exclusively deep-water marine. At the ichnospecific rank the nomencla- tural status of the ichnotaxon is still in a state of confusion despite the admirable attempt by Seilacher (1977) to resolve such difficulties. Seilacher distinguished seven ichnospecies, one of which, C. helicoidea Seilacher, 1977, he subsequently designated as a new ichnotaxon Spirocosmorhaphe sigmoidalis Seilacher, 1989. Unfortunately, at the same time that Seilacher (1977) attempted to resolve the nomenclatural difficulties, Ksiạżkiewicz (1977) described additional ichnospecies, some of which are clearly synonymous with several of Seilacher's. Clearly, therefore, at the ichnospecific rank the nomenclatural status of Cosmorphaphe is still confused and requires additional evaluation.

The Jamaican material appears to represent an intermediate form that exhibits characteristics similar to both $C$. gracilis Książkiewicz, 1977 and C. sinuosa Azpeita-Moros, 1833. The latter ichnospecies is characterized by widelyspaced first-order meanders but with second-order undulations with a greater wavelength than amplitude (Seilacher, 1977). C. gracilis, however, possesses second-order meanders approximately equal in height and width (Książkiewicz, 1977). Interestingly, in this context Książkiewicz (1977, p. 152) suggested that $C$. gracilis possibly represented a "juvenile" form of $C$. sinuosa. In view of the size and relatively tight first-order meanders of the Jamaican material, together with the fact that ichnospecific classification is still in need of re-evaluation, we prefer to classify our material as $C$. gracilis, but only tentatively so.

\section{Ichnogenus Helminthoida Schafhäutl, 1851 Helminthoida crassa Schafhäutl, 1851} Figure 2b

Material: Single specimen, uncollectible, and possibly a small component of a second (upper right in Fig. 2b) preserved on a large slab at Locality 2 of Figure 1.

Description: The specimen is poorly preserved in positive relief on the sole of an extremely weathered, medium-grained turbiditic sandstone in association with Palaeophycus striatus Hall, 1852, which clearly post-dates it and discontinuous segments, variably impressed, of other similar diameter burrows that intersect or even partly parallel the main example (Fig. 2b). It comprises a smooth, unornamented, unbranched, string-like burrow, 2.2 to $3.0 \mathrm{~mm}$ in diameter, depending on depth of impression, that exhibits elongate and continuous segments that meander in a relatively closely spaced, parallel or sub-parallel fashion and are disposed, at least in part, in a bow-like form. Meander height is 38 to $62 \mathrm{~mm}$ and width 11 to $16 \mathrm{~mm}$.

Remarks: Helminthoida is an easily distinguishable ichnotaxon, characterized essentially by smooth, relatively thin strings, generally tightly organized into parallel and elongate continuous meanders, that are unbranched and possess no cross-overs. The ichnogenus has been considered as both a true graphoglyptid and, or, a sediment-filled burrow (Seilacher, 1977; Crimes and Crossley, 1991). A detailed review of the 

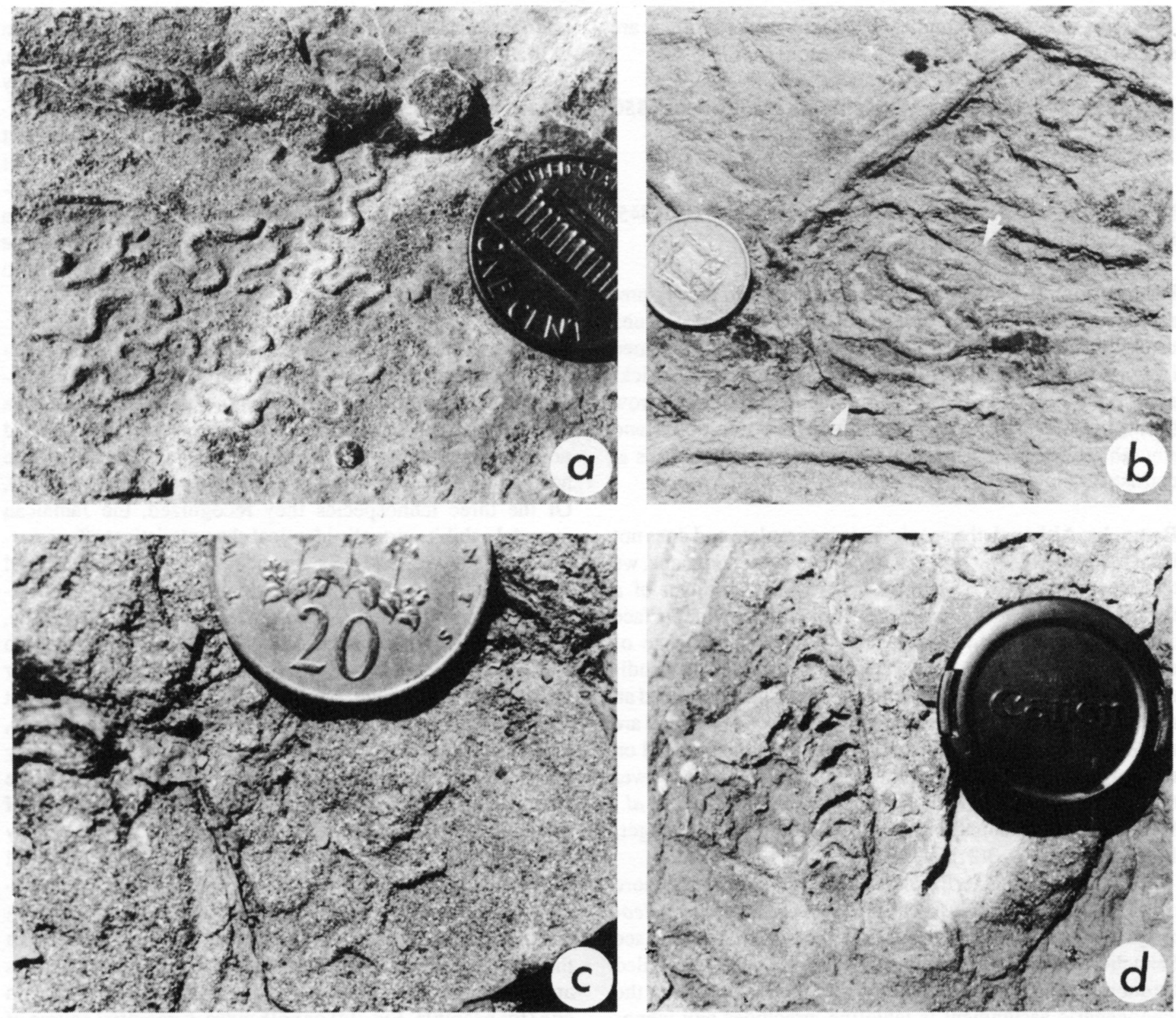

Fig. 2. (a) Cosmorhaphe cf. gracilis (to left of coin, which is $2 \mathrm{~cm}$ in diameter) cross-cut by post-depositional? Palaeophycus tubularis Hall; NBMG 8844. (b) Helminthoida crassa (to right of coin, which is $2 \mathrm{~cm}$ in diameter) cross-cut by post-depositional? Palaeophycus striatus Hall and intersected or paralleled by (for example, arrows) additional burrows. Note the small component of a possible second example (upper right) similarly intersected by $P$. striatus. (c) Paleodictyon? isp. (below coin, which is $2.9 \mathrm{~cm}$ in diameter); NBMG 8845 . (d) Taenidium cameronensis (to left of lens hood which is $5.7 \mathrm{~cm}$ in diameter); note the overlapping menisci that to the right have resulted in an apparent mantle and to the left an apparent wall structure. Specimens a to $c$ preserved on sandstone soles and $d$ on an upper bedding surface.

nomenclatural history of the three most commonly reported ichnospecies of Helminthoida and their proposed synonyms was recently presented by Crimes and Crossley (1991). Herein we follow their recommendations on ichnospecific assignments. Thus, $\boldsymbol{H}$. crassa represents a simple, regularly spaced, broadly parallel meandering burrow system arranged in a bow-like form that tends towards a spiral development at one end; $H$. labyrinthica Heer, 1865 is smaller, with denselyguided meanders and a distinct tendency to coil; and $H$. miocenica Sacco, 1886 exhibits lower, less compressed meanders and a completely unbowed form, revealing an absence of any tendency to coil (Crimes and Crossley, 1991). Additional valid and available ichnospecies include $H$. reflecta Seilacher, 1977, H. helminthopsoidea (Sacco, 1888), H. aculeata Książkiewicz, 1977, H. alterna Książkiewicz, 1977 and $H$. serrata Książkiewicz, 1977, though these are not widely reported ichnospecies and require further taxonomic assessment. Nevertheless, all these latter forms differ from the Jamaican specimen which clearly falls within $H$. crassa and is identified as such. $\boldsymbol{H}$. crassa ranges from the Lower Cambrian, where it occurs in shallow-water strata (Crimes and Anderson, 1985), to at least the Oligocene (Książkiewicz, 
1977). As with Cosmorhaphe, post-Cambrian recordings are essentially from deep-marine flysch sequences.

\section{Ichnogenus Paleodictyon Meneghini in Murchison, 1850 Paleodictyon? isp. Figure 2c}

Material: A single fragmentary specimen, NBMG 8845, from Locality 1 of Figure 1.

Description: The specimen is incompletely and poorly preserved in positive relief on the sole of a medium-grained turbiditic sandstone. It consists of a portion of a presumed incomplete network structure, approximately $1 \mathrm{~mm}$ in thickness, in which there is an unornamented central burrow (string), $8 \mathrm{~mm}$ in length, from which two additional and smooth strings are each initiated at its distal extremities at consistent angles of 115 to $120^{\circ}$.

Remarks: Although the specimen is incomplete and does not form a "meshwork" in the classic sense of the ichnogenus, we tentatively regard it as a possible erosional remnant of a formerly more complete example. The bedding plane surface containing the specimen possesses abundant evidence of scour in the form of tool marks, groove structures and rudimentary flutes, thereby suggesting that erosion was indeed an active process. Moreover, examples of Paleodictyon, that are similarly incomplete meshworks, have been documented on several occasions [for example, Webby, 1969, fig. 2a, lower right; Chamberlain, 1971, pl. 31, figs. 5-7; Crimes et al., 1992, fig. 4B; and particularly Hantzpergue and Branger, 1992, pl. 2(1), fig. 3(3)].

McCann and Pickerill (1988), Pickerill (1990) and more recently Crimes and Crossley (1991) have noted that Paleodictyon and its numerous ichnospecies (for example, see Seilacher, 1977; Książkiewicz, 1977) are in need of detailed taxonomic revision; this, together with the fact that even the ichnogeneric assignment is tentative, precludes any ichnospecific assessment. The ichnotaxon ranges through the Phanerozoic and although rare examples occur in shallowwater marine and terrestrial sequences (see Pickerill, 1990; Hantzpergue and Branger, 1992), characteristically it is a deep-water flysch trace fossil.

\section{Ichnogenus Taenidium Heer, 1877 \\ Taenidium cameronensis (Brady, 1947) Figure 2d}

Material: Nineteen specimens, all uncollectible, preserved on large, loose slabs on a relatively narrow storm beach at Locality 1 of Figure 1.

Description: Horizontal, unbranched, unlined, unwalled, straight, curved or slightly sinuous burrows preserved on upper bedding plane surfaces of medium-grained turbiditic sandstones. Preserved length variable, maximum of $16 \mathrm{~cm}$; diameter 1 to $2 \mathrm{~cm}$, commonly 1.2 to $1.5 \mathrm{~cm}$, and relatively constant in individual examples. Burrow fill essentially similar in grain size to host material and comprises deeply concave, tending towards parabolic, longer than wide, irregularly spaced and typically unequally-thick meniscae, each differentiated by thinner intermeniscate portions of material that has weathered-out. Adjacent meniscae are consistently or irregularly arcuate with respect to the long axis of an individual burrow and tend to enclose or wrap around each other. In several specimens meniscae are apparently slightly imbricate (cf. Brady, 1947, pl. 69, 2), though vertical sectioning to verify this was not possible.

Remarks: At the ichnogeneric rank, Taenidium is differentiated from several morphologically similar meniscate ichnotaxa by being unbranched, essentially unlined, and lacking a distinct wall or mantle. Despite its complex and varied nomenclatural history, a detailed and revised taxonomic analysis was undertaken by D'Alessandro and Bromley (1987). Of the three ichnospecies they recognized, the Jamaican material exhibits virtually identical characteristics to $T$. cameronensis (Brady, 1947), as emended by D'Alessandro and Bromley (1987, p. 754), and is identified as such. Unfortunately, they did not include $S$ colecocoprus arizonensis Brady, 1947 in their taxonomic considerations. Like D'Alessandro and Bromley (1987), we regard Scolecocoprus as a junior synonym of Taenidium, but find it puzzling that they did not include T. arizonensis (Brady, 1947) in their synonymy, particularly as this ichnospecies exhibits, and more clearly than $T$. cameronensis, the essential characteristics of the emended diagnosis of the ichnotaxon. To promote stability of usage, however, we utilize $T$. cameronensis as adopted by D'Alessandro and Bromley (1987). As with the material described herein, an essential characteristic of this ichnospecies is that because of the arc of the meniscae, adjacent sedimentary packets tend to nest one around the next. With the Jamaican material this commonly results in the burrows apparently possessing a well-defined wall, or even mantle, on one (for example, Fig. 2d) or both sides, a potential source of confusion with the distinctly walled ichnotaxon Beaconites Vyalov, 1962 or the mantled ichnotaxon Ancorichnus Heinberg, 1974 (see also Bromley, 1990). D'Alessandro and Bromley (1987) stated that all previous references to $T$. cameronensis were from shallow-water depositional settings. However, the recording herein, and that by Książkiewicz [1977, plate 3.16 - as Keckia cf. hoessi (Sternberg), questionably included by D'Alessandro and Bromley (1987) as Taenidium, but herein regarded as conspecific with T. cameronensis], clearly suggests that it is a facies-crossing ichnotaxon.

\section{Discussion and Conclusions}

As previously noted, Pickerill and Donovan (1991) and Pickerill et al. (1992) recognized two mutually-exclusive, environmentally-restricted ichnocoenoses within strata of the Richmond Formation. They defined a Thalassinoides ichnocoenosis, comprising Thalassinoides suevicus (Rieth), 
Teredolites clavatus Leymerie, Conichnus conicus Myannil and Arenicolites Salter, that was associated with marginaland shallow-marine depositional settings and a Scolicia ichnocoenosis, comprising Scolicia cf. plana Książkiewicz, Subphyllochorda laevis Książkiewicz, Trichichnus linearis Frey, Neonereites multiserialis Pickerill and Harland, Phycodes Richter and three ichnospecies of Helminthopsis Heer, that was restricted to relatively deep-marine turbiditic strata. The ichnotaxa Palaeophycus tubularis Hall, Palaeophycus striatus Hall, Planolites beverleyensis (Billings) and Skolithos Haldeman each occurred in the two ichnocoenoses and were therefore regarded as facies-crossing forms common to both.

The ichnotaxa described herein not only represent their first recording from Jamaica, but also from the Caribbean in general. Within the Richmond Formation they each occur within relatively deep-water turbiditic sandstone sequences as determined by detailed sedimentological observations (Westcott and Ethridge, 1983; Mann and Burke, 1990). At locality 1, Paleodictyon and Taenidium cameronensis occur in association with abundant Scolicia cf. plana, Palaeophycus tubularis, Helminthopsis and Skolithos. At locality 2, Helminthoida crassa occurs with the same ichnotaxa together with Palaeophycus striatus and Trichichnus linearis and at locality 3, Cosmorhaphe cf. gracilis occurs in association with Palaeophycus tubularis and Trichichnus linearis. Collectively, these observations suggest that the ichnotaxa documented herein can best be regarded as integral members of the deep-water Scolicia ichnocoenosis. This is hardly surprising, as the new recordings include at least two graphoglyptid ichnotaxa (C. cf. gracilis, Paleodictyon?) and a possible third ( $H$. crassa) that, elsewhere, in coeval sequences, have only been reported from deep-water turbiditic strata. The fourth ichnotax on, T. cameronensis, represents an undoubted deep-water occurrence and the conclusion of D'Alessandro and Bromley (1987) that conspecific forms are shallow-water marine can be considered somewhat premature.

The recordings herein increase the diversity of the $\mathrm{Scol}$ icia ichnocoenosis to 16 clearly recognizable ichnotaxa. Unfortunately, the nature of the commonly vertical cliff-like and deeply-weathered exposures precludes analysis of tiering and other relationships within this ichnocoenosis, particularly as most ichnotaxa, with the exception of S.cf.plana, are characteristically patchily distributed (cf. Leszczyniski and Seilacher, 1991) and overlapping or cross-cutting relationships cannot easily and realistically be assessed. Additionally, most ichnotaxa, as indeed those documented herein, occur in relatively low numbers so that it is even difficult to accurately document whether several represent the activity of pre-depositional background or post-depositional organisms (see Seilacher, 1981). Of particular interest, however, is the previously unreported occurrence of the two, possibly three, graphoglyptid ichnotaxa. Pickerill and Donovan (1991) suggested that the apparent absence of graphoglyptid ichnotaxa from turbiditic strata of the Richmond Formation was perhaps related to two factors. First, such strata were depos- ited in relatively shallow-water depths proximal to their source terrane, as inferred from the overall palaeoenvironmental setting of a fan delta-submarine fan system and the palaeobathymetric ranges of foraminiferal assemblages reported by Scott (1987) as either simply marine or outer neritic. Thus, water depth (and related environmental parameters) was regarded as too shallow for the development of such graphoglyptids. Second, and in combination, mudstones interbedded with the turbiditic sandstones are rich in organic matter, a natural food resource, and this organic matter was presumably so abundantly available that organisms had no necessity to optimally utilize a given surface area and produce graphoglyptids (cf. D'Alessandro et al., 1986).

While these observations are still difficult to dispute and still remain extremely plausible, the discovery of, albeit rare, graphoglyptids necessitates additional comment. A possible alternative explanation for the "general" absence of graphoglyptids is that burrowers responsible for their production were excluded from the muds as a result of dysaerobic or even anoxic conditions at, or particularly immediately below, the sediment-water interface, where the majority of graphoglyptids are produced prior to subsequent casting by turbidite deposition (Seilacher, 1977). Such conditions, as reflected by high organic content, dark colouration, presence of undisturbed lamination and general absence of bioturbation, and the presence of authigenic pyrite, are considered to have constituted the prevailing interstitial environment during deposition of the finer-grained sediments of the deepwater facies. Such an environment would, of course, have been inimical to the establishment of an infaunal benthos (see Pickerill and Brenchley, 1991, and references therein). However, within deep-water regimes it is not uncommon for redox conditions to exhibit episodic fluctuations so that the lower part of the water column and the muds at or immediately below the sediment-water interface can become temporarily oxygenated (for example, Savrda and Bottjer, 1986, 1989a, 1989b). In such situations, elevated oxygen levels typically result in the temporary establishment of both epifaunal and infaunal communities within an otherwise generally anoxic or dysaerobic environmental regime. Although in the Richmond Formation there is no direct evidence for fluctuating redox conditions, such a scenario could have resulted in the periodic establishment of infaunal organisms responsible for the production of the graphoglyptid and other ichnotaxa ultimately preserved on a low proportion of sandstone soles. While such fluctuations in redox conditions are more commonplace in deep-water regimes (Savrda and Bottjer, 1986, 1989a, 1989b), they can exist in "neritic" water depths, similar to those envisaged during deposition of the relatively deep-water lithofacies of Richmond Formation, as a result of upward expansion of the oxygen minimum layer intersecting the sediment-water interface (for example, Leggett, 1978, 1980; Pickerill and Hurst, 1983). Thus, the general exclusion of graphoglyptids in the Scolicia ichnocoenosis may well reflect a combination of the relatively shallow-water depths in which the turbiditic strata accumulated, the presence of abundant organic matter available for biological consump- 
tion and the existence of fluctuating dysaerobic/anoxic and oxygenated conditions at, or immediately below, the sediment-water interface.

\section{Acknowledgements}

We thank Angel Gomez, Robert McCulloch and Diane Tabor for technical assistance during preparation of this manuscript, and Kevin Pickering for discussion during fieldwork. Constructive reviews were provided by David Keighley and Guy Narbonne. Financial assistance was provided to R.K.P. by a Natural Sciences and Engineering Research Council of Canada operating grant (OGP000357) which is gratefully acknowledged.

Azpeita-Moros, F. 1933. Datos para el estudio paleontólogico del Flysch de la Costa Cantábrica y de algunos otros puntos de España. Boletín Instituto Geológica y Minero de España, 53, pp. 1-65.

Brady, L.F. 1947. Invertebrate tracks from the Coconino Sandstone of northern Arizona. Journal of Paleontology, 21, pp. 466-472.

Bromley, R.G. 1990. Trace fossils: biology and taphonomy. Unwin Hyman, London, 280 p.

Chamberlain, C.K. 1971. Morphology and ethology of trace fossils from the Ouachita Mountains, southeast Oklahoma. Journal of Paleontology, 45, pp. 212-246.

Crimes, T.P. and ANDerson, M.M. 1985. Trace fossils from Late Precambrian-Early Cambrian of southeastern New foundland (Canada): temporal and environmental implications. Journal of Paleontology, 59. pp. 310-343.

Crimes, T.P. and Crossley, J.D. 1991. A diverse ichnofauna from Silurian flysch of the Aberystwyth Grits Formation. Geological Journal, 26, pp. 27-64.

Crimes, T.P., Garcia Hidalgo, J.F., and Poire, D.G. 1992. Trace fossils from Arenig flysch sediments of Eire and their bearing on the early colonization of the deep sea. Ichnos, 2 , pp. 61-77.

D'Alessandro, A. and Bromley, R.G. 1987. Meniscate trace fossils and the Muensteria - Taenidium problem. Palaeontology, 30, pp. 743-763.

D'Allesandro, A., Ekdale, A.A., and Sonnino, M. 1986. Sedimentologic significance of turbidite ichnofacies in the Saraceno Formation (Eocene), southern Italy. Journal of Sedimentary Petrology, 56, pp. 294-306.

Ethridge, F.G. and Westcotr, W.A. 1984. Tectonic setting, recognition and hydrocarbon reservoir potential of fan-delta deposits. In Sedimentology of Gravels and Conglomerates. Edited by E.H. Koster and R.J. Steel. Canadian Society of Petroleum Geologists, Memoir 10, pp. 213-235.

Fuchs, T. 1895. Studien uber Fucoiden und Hieroglyphen. Denkschriften der Kaiserlichen Akademie der Wissenschaften, Mathematisch - Naturwissenschaftliche Klasse, 62, pp. 369-448.

Green, G.W. 1977. Structure and stratigraphy of the Wagwater Belt, Kingston, Jamaica. Overseas Geology and Mineral Resources, Institute of Geological Sciences, London, 48, 21 p.

Ha LL, J. 1852. Paleontology of New York. Volume II. Containing descriptions of the organic remains of the Lower Middle
Division of the New York System (equivalent in part to the Middle Silurian rocks of Europe). C. van Benthuysen, Albany, 362 p.

Hantzperoue, P. and Branger, P. 1992. L'ichnogenre Paleodictyon dans les dépôts néritiques de l'Oxfordien Supérieur Nord-Aquitain (France). Géobios, 25, pp. 195-205.

Heer, O. 1864-1865. Die Urwelt der Schweitz. Mit sieben landschaftlichen Bildern, elf Tafeln, einer geologischen Uebersichtskarte der Schweitz und zahlreichen in den Text eingedruckten Abhaldungen. Friedrich Schulthess, Zurich, 622 p.

1876-1877. Flora fossilis Helvetiae. Die vorweltliche Flora der Schweitz. Verlag J. Würster, Zurich, 182 p.

Heinbero, C. 1974. A dynamic model for a meniscus-filled tunnel (Ancorichnus n. ichnogen.) from the Jurassic Pecten Sandstone of Milne Land, East Greenland. Rapports Grønlands Geologiske Undersøgelse, 62, 20 p.

JiANO, M.J. and RoBinSON, E. 1987. Calcareous nannofossils and larger foraminifera in Jamaican rocks of Cretaceous to early Eocene age. In Proceedings of a workshop on the status of Jamaican geology. Edited by R. Ahmad. Geological Society of Jamaica, Special Issue, pp. 24-51.

KsiążKIewicz, M. 1977. Trace fossils in the flysch of the Polish Carpathians. Palaeontologica Polonica, 36, pp. 1-208.

LeooetT, J.K. 1978. Eustacy and pelagic regimes in the Iapetus Ocean during the Ordovician and Silurian. Earth and Planetary Science Letters, 41, pp. 163-169.

1980. British Lower Palaeozoic black shales and their palaeo-oceanographic significance. Journal of the Geological Society of London, 137, pp. 139-156.

Leszczý̃ski, S. and Seilacher, A. 1991. Ichnocoenoses of a turbidite sole. Ichnos, 1, pp. 293-303.

MANn, P. and Burke, K. 1990. Transverse intra-arc rifting: Palaeogene Wagwater Belt, Jamaica. Marine and Petroleum Geology, 7, pp. 410-427.

McCann, T. and Pickerill, R.K. 1988. Flysch trace fossils from the Cretaceous Kodiak Formation of Alaska. Journal of Paleontology, 62, pp. 330-348.

Miller, W., III. 1991. Paleoecology of graphoglyptids. Ichnos, 1, pp. 305-312.

MURChIson, R.I. 1850. Memoria sulla struttura geologica delle Alpi, delle Apennini e dei Carpazi. Stamperia granucale, Firenze, 528 p.

Narbonne, G.M., Myrow, P., Landino, E., and Anderson, M.M. 1987. A candidate stratotype for the PrecambrianCambrian boundary. Canadian Journal of Earth Sciences, 24. pp. 1277-1293.

Pickerill, R.K. 1990. Nonmarine Paleodictyon from the Carboniferous Albert Formation of southern New Brunswick. Atlantic Geology, 26, pp. 157-163.

Pickerill, R.K. and Brenchley, P.J. 1991. Benthic macrofossils as palaeoenvironmental indicators in marine siliciclastic facies. Geoscience Canada, 18, pp. 119-138.

Pickerill, R.K. and Donovan, S.K. 1991. Observations on the ichnology of the Richmond Formation of eastern Jamaica. Journal of the Geological Society of Jamaica, 28, pp. 19-35.

Pickerill, R.K. and Hurst, J.M. 1983. Sedimentary facies, depositional environments, and faunal associations of the Lower Llandovery (Silurian) Beechill Cove Formation, Arisaig. Nova Scotia. Canadian Journal of Earth Sciences, 20, pp. 1761-1779.

Pickerill, R.K., Donovan, S.K., and Dixon, H.L. 1992. The 
Richmond Formation of Eastem Jamaica Revisited - Further Ichnological Observations. Caribbean Journal of Science, 28, pp. 89-98.

SACCo, F. 1886. Intorno ad alcune impronte organiche dei terreni berziari del Piemonte. Academia della Scienze di Torino, Atti, 21, pp. 927-949.

1888. Note di Paleoichnologie Italiana. Societa Italiana di Scienze Naturali, Atti, 31, pp. 151-191.

SA vrdA, C.E. and BotTJER, D.J. 1986. Trace-fossil model for reconstruction of paleo-oxygenation in bottom waters. Geology, 14, pp. 3-6.

1989a. Trace-fossil model for reconstructing oxygenation histories of ancient marine bottom waters: application to Upper Cretaceous Niobrara Formation, Colorado. Palaeogeography, Palaeoclimatology, Palaeoecology, 74, pp. 49-74.

1989b. Anatomy and Implications of Bioturbated Beds in "Black Shale" Sequences: Examples from the Jurassic Posidonienschiefer (Southern Germany). Palaios, 4, pp. 330342.

SChafнäUth, K.E. 1851. Geognostiche Untersuchungen des Südbayrischen Alpengebirges. Literarisch-artische Ansalt, München, 208 p.
Scott, W. 1987. Age and provenance of the Richmond Formation of the Rio Grande Valley, eastern Jamaica. In Proceedings of a workshop on the status of Jamaican geology. Edited by $\mathbf{R}$. Ahmad. Geological Society of Jamaica, Special Issue, pp. 52 68.

Seilacher, A. 1977. Pattern analysis of Paleodictyon and related trace fossils. In Trace fossils 2. Edited by T.P. Crimes and J.C. Harper. Geological Journal Special Issue 9. Seel House Press, Liverpool, pp. 289-334.

1981. Towards an evolutionary stratigraphy. Acta Geologica Hispanica, 16, pp. 39-44.

1989. Spirocosmorphaphe, a new graphoglyptid trace fossil. Journal of Paleontology, 63, pp. 116-117.

Vyalov, O.S. 1962. Problematica of the Beacon Sandstone at Beacon Height West, Antarctica. New Zealand Journal of Geology and Geophysics, 5, pp. 718-732.

Webiy, B.D. 1969. Trace fossils (Pascichnia) from the Silurian of New South Wales, Australia. Paläontologische Zeitschrift, 43. pp. 81-94.

Wescott, W.A. and Ethridge, F.G. 1983. Eocene fan deltasubmarine fan deposition in the Wagwater Trough, eastcentral Jamaica. Sedimentology, 30, pp. 235-247. 